\title{
IDEE ANTROPOGEOGRAFICZNE W PRACACH MARII DOBROWOLSKIEJ (1895-1984)
}

Zarys treści Antropogeografia polska, zwłaszcza okresu międzywojennego, pozostaje jednym z kluczowych okresów do odniesień w badaniach nad zmiennością geograficznych wzorców i podejść badawczych. Szczególnie interesująco wyglądają te kwestie w przypadku geografów, których droga naukowa warunkowana była przez różne wydarzenia zmieniające bieg historii państwa i narodu. Zasadniczym celem opracowania jest próba identyfikacji przewodnich myśli autorki o charakterze koncepcyjnym, które z jednej strony decydowały o pewnych niezmiennych postawach teoretyczno-metodologicznych ukształtowanych w okresie II Rzeczpospolitej, z drugiej zaś stanowiły modernizację tych założeń pod wpływem uwarunkowań o charakterze polityczno-ideologicznym. Wiele prac odwołujących się do idei ewolucjonizmu społecznego (np. ewolucja krajobrazu rolniczego) nie zostało zakończonych lub uwieńczonych publikacją do 1939 roku, a po wojnie na założenia oraz wnioski wpływały interpretacje zmienności struktur społeczno-gospodarczych w duchu ideologii marksistowskiej. Tworzyło to eklektyczną metodologicznie interpretację przemian. Prace Marii Dobrowolskiej w zakresie przemian krajobrazu kulturowego oraz zmienności osadnictwa w ciągu wieków miały również taki charakter. Antropogeografia, której ambitnym celem było dążenie do wyjaśniania całościowego, dobrze korespondowała z koncepcjami ewolucji społecznej operującymi analogiami organicznych całości. Podkreślanie przez geografię związku człowieka ze środowiskiem przyrodniczym wzmacniało w geografach ukształtowanych w okresie międzywojennym adekwatność organicyzmu do badań rozwoju społecznego w kontekście zróżnicowań środowiska naturalnego oraz ruchliwości przestrzennej, co niewątpliwie było cechą badań M. Dobrowolskiej nad ewolucją krajobrazu kulturowego i sieci osadniczej, zwłaszcza w okresie po II wojnie światowej.

Słowa kluczowe Antropogeografia, koncepcje, metodologia, Maria Dobrowolska. 


\section{Wprowadzenie}

Antropogeografia polska, zwłaszcza okresu międzywojennego, pozostaje jednym z kluczowych okresów do odniesień w badaniach nad zmiennością geograficznych wzorców i podejść badawczych (por. np. Jackowski, Taborska 2014). Istotne dla zrozumienia idei antropogeografii jest wniknięcie w sferę podstaw teoretycznych i metodologicznych, a tym samym zagłębienie się w opracowania z tamtego okresu i zwrócenie szczególnej uwagi na sposoby myślenia o przedmiocie badań W badaniach rozwoju geografii społeczno-ekonomicznej (człowieka) najczęściej przyjmuje się model historyczno-problemowy, tzn. chronologicznego opisu podejmowanych tematów z charakterystyką najważniejszych wyników prac naukowych (por. np. Jackowski i in. 2008). Rzadszym sposobem oceny dorobku i charakteru dyscypliny jest próba rekonstrukcji przedmiotowej. Próby interpretacji przemian geografii społeczno-ekonomicznej były przedmiotem zainteresowania różnych autorów, zazwyczaj w okresie przesileń o charakterze społeczno-politycznym (por. Kukliński 1983; Chojnicki 1985; Maik 1988; Rykiel 1988).

Analiza myśli twórców geograficznych, zwłaszcza w zakresie geografii człowieka (społeczno-ekonomicznej) jest ciekawa z wielu punktów widzenia, np. rozwoju ścieżki naukowej i relacji o charakterze mistrz-uczeń, umiejscowienia warsztatu pracy, tj. kwestii rangi i specyfiki ośrodka badawczego, a także stopnia zainteresowania teorią i jej powiązaniem z filozofią. Szczególnie interesująco wyglądają te kwestie w przypadku geografów, których droga naukowa warunkowana była przez różne wydarzenia zmieniające bieg historii państwa i narodu. Do osób takich bez wątpienia należy Maria Dobrowolska, której sylwetka naukowa ukształtowana została w okresie odrodzenia Polski i budowy struktur naukowych w XX-leciu międzywojennym, doświadczonej w okresie okupacji hitlerowskiej, a następnie wystawionej na różnego rodzaju próby związane ze zmianą wzorca teoretyczno-metodologicznego geografii pod wpływem narzuconej Polsce władzy komunistycznej. Ocena zawartości prac naukowych z tego punktu widzenia jest $\mathrm{z}$ trudna, ze względu na potrzebę oddzielenia $\mathrm{w}$ analizie treści naukowej od ideologicznej, a także $z$ uwagi na eklektyzm postaw teoretyczno-metodologicznych wynikający z nakładania się starszych i nowszych rozwiązań. Zasadniczym celem opracowania jest próba identyfikacji przewodnich myśli autorki o charakterze koncepcyjnym, które z jednej strony decydowały o pewnych niezmiennych postawach teoretyczno-metodologicznych ukształtowanych w okresie II Rzeczpospolitej, z drugiej zaś stanowiły modernizację tych założeń pod wpływem uwarunkowań o charakterze polityczno-ideologicznym. Przedmiotem zainteresowania były kluczowe prace Marii Dobrowolskiej wydane w okresie XX-lecia międzywojennego wraz z pierwszymi artykułami powojennymi, które nie zostały opublikowane wcześniej w wyniku wybuchu II wojny światowej oraz kluczowe opracowania zawierające dyrektywy badawcze w okresie przebudowy 
struktur osadniczych Polski południowej pod wpływem socjalistycznej industrializacji. Specyfiką badania myśli jest zatem poszukiwanie wpływów różnych idei antropogeograficznych oraz sposób w jaki łączyły się one później w nowymi koncepcjami wynikającymi przede wszystkim z oddziaływania wzorca ekonomistycznego ${ }^{1}$.

\section{Geneza polskiej antropogeografii}

Przełom XIX i XX wieku był okresem usamodzielnienia się nowej dyscypliny geograficznej - antropogeografii. Zdaniem D. Jędrzejczyka (1997, s. 9) jej oryginalność względem innych dziedzin wiedzy polegała na określaniu relacji pomiędzy człowiekiem i podłożem (ziemią) oraz identyfikacji typów krajobrazu, które powstają w wyniku tego związku. B. Zaborski i A. Wrzosek (1937-1939, s. 4) pisząc wprowadzenie do obszernego dzieła nt. istoty i problematyki badawczej antropogeografii stwierdzili, że jej odrębność poznawcza wynika z idei rozciągłości. Autorzy uważali, że badając zjawiska, antropogeograf przede wszystkim zwraca uwagę na ich rozciągłość, tzn. stara się dociec, gdzie one występują, na jakiej powierzchni. Celem jest zatem dogłębne wyjaśnienie zjawisk antropogenicznych, określenie korelacji pomiędzy grupą zjawisk ludzkich oraz przyrodniczych oraz wzajemnych współzależności zjawisk ludzkich ze sobą.

Wielcy klasycy antropogeografii (geografii człowieka) - F. Ratzel, P. Vidal de la Blache - kształtowali swoje poglądy m.in. pod wpływem myśli przedstawicieli innych nauk, zarówno przyrodniczych i społecznych. Szczególną rolę w krystalizacji idei antropogeograficznych odgrywał pozytywizm oraz ewolucjonizm społeczny. Prace filozofa A. Comte'a i przyrodnika K. Darwina dały nową perspektywę w ocenie roli człowieka (społeczeństwa) w przyrodzie. W antropogeografii bardzo popularne stały się próby wyjaśnienia zjawisk gospodarczych i osadniczych w kategoriach organicystycznych. Zainteresowanie funkcjami organów (organizmów) przez badaczy społecznych było jedną z przyczyn rozwoju paradygmatu naukowego nazwanego naturalizmem lub naturalistycznym pozytywizmem. Najważniejszą jego cechą było przełożenie praw rządzących przyrodą na zjawiska i procesy społeczne (por. Rembowska 2006). Społeczny ewolucjonizm miał duże znaczenie w kształtowaniu się antropogeografii, która koncentrowała się na studiach relacji człowiek-przyroda (por. Jędrzejczyk 1997). Badania związku materialnych form zamieszkiwania i gospodarowania, ich rozwoju i zmienności ze strukturami środowiska przyrodniczego, zwłaszcza w kontekście idei determinizmu przyrodniczego, legły u podstaw organicystycznej interpretacji instytucji społecznych i politycznych (np. państwo, naród, region, wspólnoty regionalne i lokalne). Pojęcia komórek, tkanek, organów i narządów miały swoje analogie społeczne (Sztompka 2005, s. 103-104). Funkcjonowanie społeczeństwa, a także

\footnotetext{
${ }^{1}$ Nazwa „wzorzec ekonomistyczny” za: Z. Rykiel (1994).
} 
form organizacji społecznej (miasto, państwo) porównywano do funkcjonowania organizmu, którego różne elementy były nieodzowne dla integracji struktury, jej rozwoju i ciągłości (por. Babicz 1965, s. 56-58). Antropogeografia wpisywała się w społeczno-intelektualny „klimat” drugiej połowy XIX wieku, który wynikał z zafascynowania badaczy społecznych naukami przyrodniczymi. H. Spencer, formułując naturalistyczne pojęcie ewolucji, zawęził ją do sfery materii, która ewoluuje od chaotycznej i jednorodnej struktury do porządku opartego na zróżnicowaniu (Sztompka 2005). Powszechną zasadą, według H. Spencera, jest ewolucja każdej sfery środowiska przyrodniczego i społecznego, od układów prostych do złożonych. W ten sam sposób autor przedstawiał historię społeczeństwa, gdzie pierwotna homogeniczna organizacja społeczna różnicuje się pod względem budowy i pełnionych funkcji.

Wpływ idei F. Ratzla na polską myśl antropogeograficzną był pod koniec XIX wieku stosunkowo duży, choć od okresu publikacji prac P. Vidala de la Blache'a (początek XX wieku) szybko wrastało również zainteresowanie koncepcjami podmiotowej roli człowieka w kształtowaniu środowiska (Jędrzejczyk 1997, s. 33). Znawcy polskiej myśli antropogeograficznej dowodzą, że polscy geografowie nie przyjmowali wprost wzorca F. Ratzla, który stanowił dla nich bardziej punkt odniesienia niż model do adaptacji założeń na rodzimy grunt badań naukowych (Jędrzejczyk 1997, s. 50).

Ogromne zasługi dla rozwoju myśli geograficznej miał również socjologizm E. Durkheima. Jedną z przewodnich cech francuskiego funkcjonalizmu było teoretyczne i empiryczne określenie relacji jednostki ze społeczeństwem. Specyfika podejścia E. Durkheima polegała na przyjęciu założenia, że nauka nie zajmuje się ideologią, ale rzeczami. Fakty społeczne traktował zatem jak ,rzeczy”, bez emocji, dogmatów filozoficznych i potocznego wyobrażenia o nich. Świat społeczny ujęty był abstrakcyjnie, w sposób wyodrębniony z pierwotnych sądów i sprowadzony do najbardziej zewnętrznych, sprawdzalnych zjawisk (Szacki 1983, s. 418). Ewolucja społeczna polega, według francuskiego socjologa, na coraz większej dyferencjacji ról zawodowych jako pochodnej m.in. zmian demograficzno- i gospodarczo-przestrzennych (koncentracja ludności związana z industrializacją). Wygodnym narzędziem analizy ewolucyjnej E. Durkheima stała się opozycja typów społeczeństwa skonstruowanych według kryterium dominacji rodzajów więzi społecznej, które autor nazwał „,solidarnością mechaniczną" (homogeniczność funkcjonalna) oraz ,solidarnością organiczną” (heterogeniczność funkcjonalna). Model społeczeństwa zarysowany przez francuskiego socjologa stał się podstawą nowego sposobu wyjaśniania człowieka przez geografów. Szczególnie atrakcyjne dla nowego wzorca metodologicznego geografii było zwrócenie uwagi na systemową całość społeczeństwa (Jędrzejczyk 1997, s. 30). Geografia francuska, obserwując intelektualne próby opisu przez socjologów całości społecznej, podeszła krytycznie do naturalizmu F. Ratzla (deter- 
minizm środowiskowy). Twórcy francuskiej szkoły geografii człowieka stworzyli podstawy teoretyczne do opisu człowieka jako istoty historycznej, społecznej i kulturowej. Funkcjonalny zwrot geografii francuskiej, jak pisze K. Rembowska (2002, s. 58), inspirowany socjologizmem i analizą funkcjonalną E. Durkheima, spowodował poszukiwanie nowych, bardziej skomplikowanych sposobów badania relacji człowiek-przyroda. Miejsce analogii organizmu zajęły metody porównawcze i analityczne, a pojęcie ludności (ludzkości) zostało zhumanizowane do postaci społeczeństwa (wspólnot lokalnych, regionalnych). Całość w pojęciu P. Vidala de la Blache’a była z kolei emanacją obopólnego związku człowieka ze środowiskiem, który odzwierciedla się w krajobrazie (por. Rembowska 2002, s. 60).

W naukach społecznych, w tym również w polskiej socjologii początku XX wieku (np. Krzywicki 1937), wrastało dodatkowo zainteresowanie myślą marksistowską. Marksiści, przystosowując niektóre wątki myśli ewolucjonistów, stworzyli własną wykładnię zmiany społecznej, której podstawy filozoficzne zaczerpnięte $z$ heglizmu i innych prądów myślowych (np. ekonomii politycznej) zostały rozwinięte w postaci materializmu historycznego. Koncepcje K. Marksa oraz F. Engelsa krystalizowały się na tle prądów intelektualnych XIX wieku, czego przejawem było poszukiwanie ogólnych praw rozwoju historycznego społeczeństwa, również w skali globalnej. Do zasadniczych powtórzeń myśli ewolucjonistów należały tezy o postępowym charakterze rozwoju społecznego (procesu dziejowego) oraz jego etapowości, a także konsekwencji procesu dziejowego w postaci coraz większego zróżnicowania społecznego zachodzącego przede wszystkim w wyniku podziału pracy (Sztompka 2005, s. 154). Wśród wielu założeń K. Marksa, które przez ostatnie 150 lat tworzyły jedno z największych pól naukowej interpretacji dziejów społecznych, politycznych i gospodarczych świata, najważniejszą dla geografii była teoria formacji społeczno-ekonomicznych. Najbardziej istotną z geograficznego punktu widzenia jest teza o samonapędzającym się, endogennym i immanentnym charakterze przekształceń społecznych, wśród których kluczową rolę odgrywają sprzeczności pomiędzy warunkami pozaspołecznymi (przyroda) a siłami wytwórczymi determinowanymi przez możliwości technologiczne. Dialektyka społeczeństwo-przyroda określa z kolei stosunki produkcji, których całokształt na odpowiednim poziomie rozwoju stanowi „bazę” formacji. Całokształt stosunków produkcji wieńczy „nadbudowa” polityczna i prawna wraz z odpowiadającymi jej określonymi formami świadomości społecznej (Sztompka 2005, s. 168-169). Sekwencja formacji społeczno-ekonomicznych, od wspólnoty pierwotnej, niewolnictwa, feudalizmu do kapitalizmu, prowadzi ku narastaniu nierówności między klasami (wyzyskiwani i wyzyskiwacze). Rewolucja miała być niejako powrotem do stosunków społecznych opartych na wspólnej własności (środków produkcji). Formacje społeczno-ekonomiczne uważane były za pewne typy stosunków produkcji w relacji do stopnia rozwinięcia sił wytwórczych oraz nadbudowy politycznej, które następują po sobie i są swoistymi całościami społecznymi (Szacki 1983, s. 223). 
Antropogeografia polska do wybuchu II wojny światowej charakteryzowała się, jak pisze D. Jędrzejczyk (1997, s. 53), polifonicznością wyrażającą się w pluralizmie postaw i orientacji badawczych. W większym stopniu była przywiązana jednak do pozytywistycznego realizmu niż np. sądów o charakterze metafizycznym, czego przejawem była koncentracja na aspektach materialnych działalności człowieka $\mathrm{w}$ środowisku, $\mathrm{w}$ tym przede wszystkim na osadnictwie grup ludzkich rozpatrywanym na tle uwarunkowań przyrodniczych (por. Zaborski, Wrzosek 1937-1939).

\section{Wpływ idei antropogeograficznych na prace Marii Dobrowolskiej w zakresie badań krajobrazu kulturowego}

Zainteresowanie identyfikacją rozwoju krajobrazu kulturowego, w tym krajobrazów rolniczych, widoczne było od początku pracy naukowej autorki. Jedna z pierwszych prac M. Dobrowolskiej (Mrazkówna 1922) koncentrowała się na rozwoju demograficznym ziemi krakowskiej w układzie przestrzennym. Rozmieszczenie ludności oraz jego przyczyny były wówczas jednym z najbardziej powszechnych tematów prac badawczych antropogeografii. D. Jędrzejczyk (1997, s. 107) w rekonstrukcji podejść badawczych polskiej antropogeografii zauważył, że obok celu związanego z identyfikacją roli podłoża przyrodniczego w rozwoju osiedli w pracach geografów ważnym problemem było „określenie roli osadnictwa w kształtowaniu krajobrazu kulturalnego, a więc sui generis przestrzeni społeczno-gospodarczej”.

M. Dobrowolska (1922) może być pod pewnymi względami uważana za prekursorkę teoretycznych i empirycznych badań nad genezą zjawisk ludnościowo-gospodarczych oraz periodyzacji takich dziejów z punktu widzenia kształtowania się relacji człowiek-przyroda. Autorka miała krytyczne spojrzenie na jednostronną interpretację dziejów społecznych w ujęciu Ratzlowskiego determinizmu przyrodniczego. W wyjaśnieniu wzrostu ludności w dużym stopniu wskazywała na rolę struktury produkcji $\mathrm{w}$ tworzeniu się różnych form koncentracji populacji. We wczesnych interpretacjach procesów osadniczych zaznaczały się wpływy ewolucjonizmu o materialistycznym zabarwieniu. W swych pierwszych pracach M. Dobrowolska (1922, s. 106) zrywała z ujęciem krainistycznym (rozpatrywanie zjawisk społecznych na tle jednostek naturalnych) i przyjęła układ jednostek administracyjnych, uzasadniając to w następujący sposób:

„(...) pojęcie każdej jednostki fizjograficznej opiera się już w swej definicji na wartościach geograficznych [przyrodniczych - przypis M.W.], pragniemy zaś uniknąć wszystkiego, co mogłoby zabarwić i uwarunkować dalsze wnioski. Jednostka administracyjna jest przytem najodpowiedniejszą i ze względów rozwojowych, gdyż ona tylko pozwala porównać, ewentualnie zestawić ze sobą czynniki społeczne, polityczne czy ekonomiczne w pewnym okresie". 
Rozległe zainteresowania M. Dobrowolskiej na pograniczu geografii, historii i etnografii, a później również socjologii sprawiały, że jej sposób oglądu struktur osadnictwa wiejskiego wiązał się ściśle z refleksją o genezie zjawisk osadniczych, ich ewolucji i typologii w różnych układach (czasowym, przestrzennym, problemowym). Niezależnie od specyfiki dwóch głównych pól badawczych (geografia historyczna oraz geografia osadnictwa i ludności), jej prace odznaczały się ujęciem problemów struktury osadniczej (współczesnej lub historycznej) w pewnym ciągu rozwojowym. Prace te charakteryzował dualizm wzorca badawczego. Studia geograficzno-historyczne, głównie z zakresu ewolucji sieci osadniczej na tle warunków naturalnych oraz ewolucji krajobrazu rolniczego (kulturowego), cechowały się interpretacją typową dla wzorca klasycznego, choć z zauważalnymi wpływami marksistowskiego materializmu historycznego.

Tezy M. Dobrowolskiej (1948) zamieszczone po wojnie w obszernej publikacji są świadectwem interpretacji przemian społeczno-gospodarczych wsi w obrębie materialistycznego spojrzenia na ewolucję krajobrazu wsi². Droga rozwoju naukowego autorki, a tym samym zmiana sposobu interpretacji przemian społeczno-osadniczych, była systematycznym poszerzaniem teorii ewolucji osadnictwa i krajobrazu rolniczego o zasady materializmu historycznego. W ujęciu materialistycznym M. Dobrowolska (1948) interpretowała ogólną ewolucję krajobrazu kulturowego oraz współczesnych możliwości śledzenia takich zmian (nowe techniki - zdjęcia lotnicze). Zdaniem autorki antropogeografia jest nauką o współzależności ziemi i społeczeństw ludzkich. W toku dziejów, wynikiem wzajemnego oddziaływania człowieka i przyrody są krajobrazy kulturowe, czyli synteza działalności społeczeństwa w ich środowiskach (Dobrowolska 1948, s. 154-156). Krakowska badaczka traktowała społeczeństwo jako organiczną całość i tak pisała o jego przystosowaniu się do warunków środowiska:

„Na wyższych szczeblach kultury społeczeństwo pozostawia w krajobrazie w każ-dym okresie historycznym obraz swej epoki, ściślej mówiąc obraz swego sposobu przystosowania się do warunków siedliska. Przystosowanie się organizmu społecznego do środowiska w wyniku podświadomej lub świadomej reakcji grup społecznych na warunki otoczenia powoduje z jednej strony celowe rozmieszczenie grup pod względem ilościowym i jakościowym, z drugiej przetwarzanie środowiska przez gospodarczą i kulturalną działalność" (Dobrowolska 1948, s. 156).

Zadaniem M. Dobrowolskiej (1948, s. 159) metoda ewolucyjna badań krajobrazów kulturowych jest systematycznym badaniem dziejowego procesu przystosowania się ludzi do środowiska przyrodniczego, a kluczowe zadanie geografów polega na odtworzeniu faz ewolucji krajobrazu, które powodują „odkładanie się warstw kulturowych" (stratygrafia kulturowa). Jej praca zawiera nie tylko wątek opisowy i systematyzujący wiedzę (głównie z lat 20. i 30. XX wieku), ale ma również charakter wartościujący. $\mathrm{W}$ treści obszernego opracowania odbija się

\footnotetext{
${ }^{2}$ Opóźnienie wydania pracy wynikało z wybuchu II wojny światowej.
} 
intelektualny dyskurs antropogeografii i nauk społecznych związany z ideą ewolucjonizmu społecznego. Przykładem są liczne odwołania do poglądów L. Krzywickiego - międzywojennego marksistowskiego socjologa, któremu bliskie były poglądy L. Morgana. Autorka, rozważając problem rozwoju cywilizacyjnego podkreślała, że postęp, w wyniku którego dochodzi do złożoności organizacji społecznej grup ludzkich może być w konsekwencji dla nich destruktywny (Dobrowolska 1948, s. 191). Celem M. Dobrowolskiej nie było proste określenie elementów krajobrazu kulturowego oraz czynników kształtujących kierunek jego ewolucji. Autorka próbowała wprowadzić do interpretacji ewolucjonizmu zasady materializmu historycznego, określając podstawowe czynniki kształtujące stosunki produkcji jako efekt dialektyki „,siły przyrody” - ,siły wytwórcze” oraz uwydatniające czynniki polityczne jako odpowiednik „nadbudowy ideologicznej”, „korygującej” bieg ewolucji społecznej. W ten sposób stworzyła eklektyczną koncepcję zawierającą w sobie elementy klasycznej antropogeografii oraz wpływy marksistowskiej interpretacji dziejów. Ten sposób widzenia zmiany krajobrazu kulturowego, w tym również osadniczego, znalazł później rozwinięcie w wielu powojennych pracach autorki dotyczących przeobrażeń społeczno-gospodarczych wsi małopolskich w okresie gospodarki centralnie planowanej.

Wyniki kompleksowych badań M. Dobrowolskiej nad osadnictwem, głównie z bliskiego jej rodzinnie i zawodowo obszaru południowej Małopolski, ukazały się po II wojnie światowej, w niektórych przypadkach z bardzo długim opóźnieniem (por. Dobrowolska 1985). Na podstawie notatek naukowych autorki z lat 30. XX wieku (np. Dobrowolska 1931) na temat oceny przemian układów osadniczych w toku dziejowym trudno określić ówczesną podstawę metodologiczną tych studiów, choć z pewnością wpisywały się wówczas w klasyczny postulat badania relacji człowiek-środowisko przyrodnicze (typy krajobrazu). Wydana po śmierci M. Dobrowolskiej (1985) praca z zakresu geografii historycznej osadnictwa południowej Małopolski stanowiła rozwinięcie przemyśleń z okresu przedwojennego. Przeprowadzona w pracy rekonstrukcja środowiska geograficznego miała według M. Dobrowolskiej ukazać nawarstwienia kulturowe z poszczególnych faz rozwoju historycznego. Przeobrażenie struktury osadniczej widziane było jako dialektyczny związek dwóch kategorii sił, tzn. „sił przyrody” i ,sił wytwórczych” (Dobrowolska 1985, s. 9). Autorka, podobnie jak w przypadku prac dotyczących ewolucji krajobrazu kulturowego, znajdowała się pod wpływem marksistowskiej interpretacji dziejów społecznych, w której źródłem postępu jest zmiana „bazy” rozumianej jako typ stosunków produkcji. Rekonstrukcja procesu rozwoju osadnictwa opierała się na założeniu, że czynniki produkcji, których oddziaływanie jest pochodną postępu technologicznego, mają główny wpływ na ewolucję osadnictwa. Układ sieci osiedli i jej funkcje odzwierciedlają charakter działalności gospodarczej, jego zmianę oraz nowe możliwości techniczne w pokonywaniu „oporu” środowiska przyrodniczego. 


\section{Wpływ idei antropogeograficznych na prace Marii Dobrowolskiej w zakresie badań nad przeobrażeniami społeczno-gospodarczymi osadnictwa}

Koncepcja dynamiki struktur osadniczych wsi została sformułowana przez M. Dobrowolską w połowie lat 50. XX wieku, kiedy podjęła pracę na stanowisku kierownika Katedry Geografii Ekonomicznej WSP w Krakowie (Pakuła, Rajman 1975). Wydarzenie to rozpoczęło nowy etap badań geograficznych nad osadnictwem w ośrodku krakowskim. W zakresie przemian osiedli, zwłaszcza wiejskich, skoncentrowano się przede wszystkim na przeobrażeniach społeczno-gospodarczych oraz demograficzno-osadniczych. Rozpoczęty w 1958 roku cykl prac, ukazujący założenia teoretyczne oraz wyniki badań zespołu (Dobrowolska 1958, 1959), zawierał dyrektywy metodologiczne badań struktur osadniczych.

Bez wątpienia sposób widzenia problemu miał duży związek w punktem widzenia autorki ukształtowanym w okresie międzywojennym. Po II wojnie światowej duży wpływ na kierunek badań osadniczych M. Dobrowolskiej i jej zespołu miały skrystalizowane poglądy na cele badań geografii ekonomicznej oraz, co podkreśla się rzadko, socjologiczne koncepcje jej męża - K. Dobrowolskiego. Istota prowadzonych studiów nad osadnictwem $\mathrm{w}$ okresie powojennym polegała przede wszystkim na próbie całościowego opisu zmian społeczno-gospodarczych. Holistyczne spojrzenie na środowisko osadnicze było swoistym kontrapunktem względem przyjętego przez geografów paradygmatu geografii ekonomicznej opartego m.in. na specjalizacji (konferencja metodologiczna w Osiecznej), co było konsekwencją kształtowania się sylwetki badawczej autorki w okresie dominacji wzorca antropogeograficznego. W tym zakresie można M. Dobrowolską uznać $w$ naszych warunkach za jedną $\mathrm{z}$ prekursorek geografii społecznej (por. Wójcik, Suliborski 2014).

Szczególne znaczenie dla przedstawienia wizji badań przeobrażeń społeczno-gospodarczych osiedli wiejskich po II wojnie światowej miały dwie prace, tzn.:

1. Badania nad geografia osiedli poludniowej Matopolski (Dobrowolska 1958), gdzie przedstawiono zakres studiów prowadzonych w ramach pierwszych powojennych badań sieci osadniczej,

2. Dynamika struktur osadniczych $i$ ich uktadów przestrzennych - podsumowanie wieloletnich badań (Dobrowolska 1970).

M. Dobrowolska (1958, s. 93) uważała, że postawienie i rozwiązanie problemu przemian osadniczych w warunkach gwałtownej industrializacji wymaga właściwego przygotowania, które powinno obejmować:

1) powiązanie ewolucji sieci osadniczej z teorią regionu,

2) ustalenie priorytetu dla badań terenowych,

3) rozszerzenie metod badań o techniki społeczne (np. kwestionariusz ankiety). 
M. Dobrowolska (1958) podjęła dyskusję z preferowanym wówczas modelem rozwoju geografii, czyli z ujęciem branżowym. Jej zdaniem podejście specjalistyczne miało ograniczone zastosowanie, a „wąska specjalizacja w geografii ekonomicznej stanowi jedynie fragment zadań badawczych". Świadomość ta brała się z obserwacji zainteresowań innych dziedzin badań społecznych, m.in. socjologii i etnografii, co bardzo dobrze wiązało się z przedwojennym przygotowaniem autorki w zakresie antropogeografii. Zdaniem autorki, przemiany społeczno-gospodarcze wsi są interdyscyplinarnym problemem badań (Dobrowolska 1958, s. 94). Celem ostatecznym, jak pisała M. Dobrowolska (1958, s. 94) ,pozostanie zawsze «integralne odtworzenie istniejącej rzeczywistości» ze wszystkimi jej faktami, z uwzględnieniem współzależności zjawisk i zachodzących procesów”. Specyfiką badań geograficznych jest ujęcie regionalne, tzn. głównym celem geografa jest integralne wyjaśnienie odmienności regionu, czyli kompleksowe odtworzenie związków genetycznych i funkcjonalnych zachodzących pomiędzy elementami a procesami w regionie. Podstaw takiego podejścia upatrywała $\mathrm{w}$ gruntownych studiach nad przeszłością regionu, interpretowaną jako pewien mechanizm dziejowy - niezbędny do wyjaśnienia współczesnych zmian (Dobrowolska 1958, s. 95). Badania nad strukturami osadniczymi muszą, zdaniem M. Dobrowolskiej (1958), zostać powiązane $\mathrm{z}$ teorią regionu i szerzej z teorią geografii. Dla M. Dobrowolskiej (1970, s. 6) zjawiska osadnicze są zjawiskiem historycznym, rozwijającym się w czasie i należy je rozpatrywać w związku ze zmianami sposobów wytwórczości (,,siły wytwórcze” - „baza”) i społeczno-politycznymi („,nadbudowa") na gruncie regionu, którego struktury w efekcie ulegają przemianom lub tworzą się in statu nascendi (Dobrowolska 1962). Kluczową rolę odgrywał tu pogląd na dobór metody odkrywania tych relacji. Autorka twierdziła, że struktury osadniczej nie można bowiem oderwać od struktury społeczno-gospodarczej regionu, a problem odrębności, trwałości i zmienności struktury regionalnej należy widzieć w funkcjonalnym związku poszczególnych elementów (demograficzno-osadniczych, społeczno-gospodarczych, polityczno-administracyjnych) i ich rozwoju historycznego. Rozwój historyczny jest nierównomierny - w jego efekcie pewne elementy narastają, inne zaś zamierają lub giną (Dobrowolska 1970, s. 7).

Wiele ze studiów prowadzonych w zespole badawczym było szczególnym przypadkiem badań geograficzno-historycznych nad dawną strukturą społeczno-gospodarczą wsi. Dokonywano w nich wnikliwej rekonstrukcji krajobrazu agrarno-osadniczego Małopolski wraz z badaniem historii pojedynczych gospodarstw rolnych (por. Prochownik 1962, 1968a). Analiza genezy rozdrobnienia agrarnego była kluczowa dla wyjaśnienia związku pomiędzy uprzemysłowieniem a różnicowaniem się społeczno-zawodowym i przestrzennym wsi (Prochownik 1968b). Jednym z podstawowych pojęć dla budowy programu badań dynamiki struktur osadniczych było „integralne odtworzenie rzeczywistości”. Pojęcie to w polskiej socjologii wprowadził K. Dobrowolski w kontekście badań regionów kulturo- 
wych (etnograficznych). Metoda integracyjna była, zdaniem autora, sposobem na przełamywanie specjalizacji nauk społecznych, a główne jej zadanie polegało na poszukiwaniu związków funkcjonalnych pomiędzy zjawiskami społecznymi oraz określeniu roli historycznego podłoża badań. Oryginalnym pomysłem K. Dobrowolskiego było prowadzenie terenowych badań historycznych, które przez odwoływanie się do jednostkowej i zbiorowej pamięci miały uzupełniać studia archiwalne (Dobrowolski 1952).

Autorka dogłębnie przedstawiła genezę osadnictwa, naświetlając problem przemian wsi i wiejskich układów osadniczych z wielu punktów widzenia. Interpretacja procesu przemian osadniczych zakładała charakter celowy i dziejową kulminację, która wiąże się, jak podkreśla M. Dobrowolska $(1970,1976)$, $\mathrm{z}$,rewolucyjnym przekształcaniem struktur i układów osadniczych w gospodarce socjalistycznej”. Autorka utrwaliła tezę mówiącą o rewolucyjnym charakterze przemian osadniczych w okresie socjalistycznym (Dobrowolska 1970).

W ten sposób dynamika zmiany, jej totalny charakter, kierunkowość i celowość zastąpiły kluczową funkcję rewolucji w opisie przemian społeczno-osadniczych, tak jak miało to miejsce w geografii radzieckiej. M. Dobrowolska w swych pracach nie przeciwstawiała sobie gospodarki kapitalistycznej i socjalistycznej. Opisywała je jako ciąg wydarzeń, które były przede wszystkim wizją ewolucyjnych przemian osadniczych, ze szczególnym uwzględnieniem roli ostatniego etapu zmian, co wyrażało się m.in. w tytułach rozdziałów, np. rewolucyjne przekształcenie struktur osadniczych w gospodarce socjalistycznej (por. Dobrowolska 1970). Wsie identyfikowane były jako układy osadnicze ewoluujące z układów domkniętych (prostych) w układy otwarte (złożone), podporządkowane funkcjonalnie ośrodkom przemysłowym (Dobrowolska, Prochownik 1971).

\section{Podsumowanie}

Wprowadzenie ustroju socjalistycznego w Polsce na drodze drastycznej zmiany, ale bez rewolucji, miało określone konsekwencje w charakterze przemian metodologicznych geografii człowieka. Część geografów wywodzących się z międzywojennych szkół, przywiązanych m.in. do koncepcji antropogeograficznych, modyfikowała założenia badań i wprowadzała nowe wątki interpretacyjne oparte na marksistowskim materializmie historycznym. Wprowadziło to do badań naukowych pewien chaos, który wynikał z kilku uwarunkowań teoretyczno-metodologicznych.

Zorganizowany (instytucjonalny) rozwój polskiej geografii w II Rzeczypospolitej był zbyt krótki, aby mogła ona zaadaptować na szerszą skalę różne podejścia nauk społecznych oraz przedstawić ich szerszą krytyczną ocenę. Na tym tle innowacyjny charakter miały prace S. Nowakowskiego (1934-1935). Od połowy lat 30. XX wieku widoczna jest dopiero większa całościowa refleksja nad 
oddziaływaniem różnych koncepcji geograficznych i nauk społecznych na badania polskich antropogeografów oraz próby systematyzacji tej wiedzy (por. Nowakowski 1934-1935; Zaborski, Wrzosek 1937-1939; Pawłowski 1938). Wiele prac odwołujących się do idei ewolucjonizmu społecznego (np. ewolucja krajobrazu rolniczego) nie zostało zakończonych lub uwieńczonych publikacją do 1939 roku, a po wojnie na założenia oraz wnioski wpływały interpretacje w myśl ideologii marksistowskiej. Tworzyło to często eklektyczną metodologicznie interpretację przemian. Prace Marii Dobrowolskiej w zakresie przemian krajobrazu kulturowego oraz zmienności osadnictwa $\mathrm{w}$ ciągu wieków miały również taki charakter. Należy jednak zauważyć, że wpływy materializmu historycznego widoczne były w zainteresowaniach badaczki już w okresie międzywojennym, co mogło mieć związek z kształtującym się światopoglądem autorki oraz jej zainteresowaniem pracami marksizujących socjologów.

Dla polskich badań geografii człowieka po II wojnie światowej bardziej atrakcyjny był pierwotny wzorzec marksistowskiej interpretacji ewolucjonizmu społecznego (w myśl wykorzystanych założeń L. Morgana przez F. Engelsa, por. Szacki 1983) niż marksistowsko-leninowskie interpretacje dziejów społeczno-gospodarczych. Antropogeografia, której ambitnym celem było dążenie do wyjaśniania całościowego, dobrze korespondowała z koncepcjami ewolucji społecznej operującymi analogiami organicznych całości. Podkreślanie przez geografię związku człowieka ze środowiskiem przyrodniczym wzmacniało w geografach ukształtowanych w okresie międzywojennym adekwatność organicyzmu do badań rozwoju społecznego w kontekście zróżnicowań środowiska naturalnego oraz ruchliwości przestrzennej, co niewątpliwie było cechą badań M. Dobrowolskiej nad ewolucją krajobrazu kulturowego i osadnictwa, zwłaszcza w okresie po II wojnie światowej.

\section{LITERATURA}

Babicz J., 1965, Tendencje integracyjne i dezintegracyjne w geografii XIX i XX wieku, „Przegląd Zagranicznej Literatury Geograficznej”, 3.

Chojnicki Z., 1985, Orientacje filozoficzno-metodologiczne geografii - ich koncepcje i modele, ,Przegląd Geograficzny”, 57 (3), s. 255-281.

Dobrowolska M. (Mrazkówna), 1922, Z antropogeografii ziemi krakowskiej, „Przegląd Geograficzny", 2, s. 105-127.

Dobrowolska M., 1931, Osadnictwo Puszczy Sandomierskiej między Wista a Sanem, Krakowskie Odczyty Geograficzne PTG, Kraków, s. 1-26.

Dobrowolska M., 1948, Dynamika krajobrazu kulturowego, „Przegląd Geograficzny”, $21(3-4)$, s. 151-204.

Dobrowolska M., 1958, Badania nad geografia osiedli poludniowej Małopolski, „Rocznik Naukowo-Dydaktyczny", 8, Wydawnictwo Naukowe WSP, Kraków, s. 93-124. 
Dobrowolska M., 1959, Przemiany struktury społeczno-gospodarczej wsi Małopolskiej, „Przegląd Geograficzny”, 31 (1), s. 3-32.

Dobrowolska M., 1962, Dynamika ksztattowania się regionów w Polsce poludniowej po drugiej wojnie światowej, ,Rocznik Naukowo-Dydaktyczny”, 10, Wydawnictwo Naukowe WSP, Kraków, s. 89-101.

Dobrowolska M., 1970, Dynamika struktur osadniczych i ich układów przestrzennych, „Folia Geographica, Series Geographica-Oeconomica”, 3, s. 5-34.

Dobrowolska M., 1976, Ośrodki sieci osadniczej $i$ więzi społeczno-gospodarczej wsi w ich funkcjonalnych i przestrzennych przemianach, „Przegląd Geograficzny”, 48 (4), s. 613-625.

Dobrowolska M., 1985, Procesy osadnicze w dorzeczu Wistoki i Białej Dunajcowej, Prace Monograficzne, 69, Wydawnictwo Naukowe WSP, Kraków.

Dobrowolska M., Prochownik A., 1971, Urbanizacja wsi a przemiany układów osadniczych, „Folia Geographica, Series Geographica-Oeconomica”, 4, s. 5-52.

Dobrowolski K., 1952, Badania historyczno-terenowe. Zagadnienia rekonstrukcji procesów historycznych na podstawie materiałów terenowych, Sprawozdanie z posiedzeń i czynności PAU, 6, s. 424-429.

Jackowski A., Liszewski S., Richling (red.), 2008, Historia geografii polskiej, Wydawnictwo Naukowe PWN, Warszawa.

Jackowski A., Taborska, 2014, Rozwój myśli geograficznej w Polsce, Uniwersytet Jagielloński, Kraków.

Jędrzejczyk D., 1997, Antropogeografia polska XIX i XX w., Uniwersytet Warszawski, Warszawa.

Krzywicki L., 1937, Społeczeństwo pierwotne i jego wzrost, Kasa im. Mianowskiego, Warszawa.

Kukliński A., 1983, Mechanizmy rozwoju geografii polskiej w latach 1945-1982, „Przegląd Geograficzny", 40 (3-4), s. 521-546.

Maik W., 1988, Refleksje dotyczące stanu i rozwoju geografii osadnictwa w Polsce, „Seria Geografia", 42, Uniwersytet Adama Mickiewicza w Poznaniu, Poznań, s. 135-152.

Nowakowski S., 1934-1935, Geografia jako nauka $i$ dzieje odkryć geograficznych, Wydawnictwo Trzaska, Evert i Michalski, Warszawa.

Pakuła L., Rajman J., 1975, Profesor Maria Dobrowolska - w 80. rocznice urodzin, „Czasopismo Geograficzne”, 46(4), s. 407-419.

Pawłowski S., 1938, O znaczeniu geografii i jej stanowisku w rzędzie nauk, [w:] Geografia jako nauka i przedmiot nauczania, Wydawnictwo Książnica-Atlas, Lwów-Warszawa.

Prochownik A., 1962, Rozdrabnianie gospodarstw a emigracja ze wsi. Studium wsi Piotrowice Wielkie w powiecie proszowickim, ,Rocznik Naukowo-Dydaktyczny WSP w Krakowie", 10, s. 159-176.

Prochownik A., 1968a, Z badań nad przeobrażeniami struktur osadniczo-agrarnych w potudniowej Polsce, ,Rocznik Naukowo-Dydaktyczny”, 30, Wydawnictwo Naukowe WSP, Kraków, s. 109-116.

Prochownik A., 1968b, Przemiany w strukturze osadniczo-agrarnej w zapleczu Tarnobrzeskiego Ośrodka Siarkowego, „Zeszyty Badań Rejonów Uprzemysławianych”, 29, s. 71-89. 
Rembowska K., 2002, Kultura $w$ tradycji $i$ we współczesnych nurtach badań geograficznych, Wydawnictwo Uniwersytetu Łódzkiego, Łódź.

Rembowska K., 2006, Człowiek w geograficznych obrazach świata. Próba rekonstrukcji, [w:] Maik W., Rembowska K., Suliborski A. (red.), Człowiek w badaniach geograficznych. Podstawowe idee i koncepcje w geografii, t. 2, Wydawnictwo Uczelniane WSG, Bydgoszcz, s. 27-46.

Rykiel Z., 1988, The Functioning and the Development of Polish Human Geography, „Progress in Human Geography”, 12, s. 391-408.

Rykiel Z., 1994, Główne kierunki i metody badań w polskiej geografii osadnictwa, [w:] Liszewski S. (red.), Geografia osadnictwa i ludności w niepodległej Polsce. Lata 1918-1993, t. 2: Kierunki badań naukowych, PTG, Komisja Geografii Osadnictwa i Ludności, Łódź, s. 251-264.

Szacki J., 1983, Historia myśli socjologicznej, PWN, Warszawa.

Sztompka P., 2005, Socjologia zmian społecznych, Wydawnictwo Znak, Kraków.

Wójcik M., Suliborski A., 2014, Geografia społeczna w Polsce-geneza, koncepcje i zróżnicowanie problemowe ze szczególnym uwzględnieniem studiów geograficzno-miejskich w ośrodku łódzkim, [w:] Suliborski A., Wójcik M. (red.), Dysproporcje społeczne i gospodarcze w przestrzeni Łodzi. Czynniki, mechanizmy, skutki, Wydawnictwo Uniwersytetu Łódzkiego, s. 17-48.

Zaborski B., Wrzosek A., 1937-1939, Antropogeografia, Wydawnictwo Trzaska, Evert i Michalski, Warszawa.

\section{ANTHROPOGEOGRAPHICAL IDEAS IN THE WORKS OF MARIA DOBROWOLSKA (1895-1984)}

Abstract Polish anthropogeography, especially of the interwar period, still remains one of the key periods of reference in studies of geographical variation in research patterns and approaches. These issues are especially interesting in the case of geographers, whose scientific careers were shaped by various events that changed the history of the country and the nation. The main objective of this paper is to identify the guiding concepts of the author, that on one hand formed certain unchanging theoretical and methodological stances in the Second Republic, while on the other served as a modernisation of such assumptions based on political and ideological conditions. Many works referring to the idea of social evolution (e.g. the evolution of the agricultural landscape) had not been completed or published before 1939, while post-war assumptions and conclusions were heavily influenced by the interpretations of variable social and economic structures based on Marxist ideology. This created a methodologically eclectic interpretation of transformations. The work of Maria Dobrowolska discussing the transformation of cultural landscape and the variability in settlement over the ages also adhered to this. Anthropogeography, whose ambitious goal was to strive for a holistic explanation, corresponded well with the concepts of social evolution that used the analogies of organic wholes. Geography's emphasis on the 
relationship between the humans and the natural environment reinforced in geographers formed in the inter-war period the feeling that organicism was an adequate method of inquiry into social development in the context of environmental variability and spatial mobility, which was definitely visible in M. Dobrowolska's works on the evolution of cultural landscape and settlement network, especially following World War II.

Keywords Anthropogeography, concepts, methodology, Maria Dobrowolska.

Dr hab. Marcin Wójcik, prof. UŁ

Katedra Geografii Regionalnej i Społecznej

Wydział Nauk Geograficznych

Uniwersytet Łódzki 